\title{
The Initial Formation of the Reader Teacher
}

\author{
Elianeth Dias Kanthack Hernandes ${ }^{1}$, Renata Junqueira de Souza ${ }^{2}$ \\ ${ }^{1}$ Department of Administration and School Supervision, São Paulo State University (UNESP), Marilia, Brazil \\ ${ }^{2}$ Department of Education, São Paulo State University (UNESP/CELLIJ), Presidente Prudente, Brazil \\ Email: netezeu@gmail.com,recellij@gmail.com
}

Received 14 May 2016; accepted 12 June 2016; published 15 June 2016

Copyright @ 2016 by authors and Scientific Research Publishing Inc.

This work is licensed under the Creative Commons Attribution International License (CC BY).

http://creativecommons.org/licenses/by/4.0/

(c) (i) Open Access

\begin{abstract}
This work is part of a broader research and aims to analyze the initial process of building readers of teachers graduated in Language Arts at a public university in the state of São Paulo. The research problem that has guided the work parts of the following question has the Bachelor in Language Arts provided initial training to guide the formation of the fluent reader. The data collected are analyzed according to the conceptions of reading and ways of reading as a cultural practice (Chartier) and language as an instrument of mediation (Vygotsky). With this work we intend to collaborate on the development of an action plan to qualify the formation of readers.
\end{abstract}

\section{Keywords}

Training Reader Teachers, Reading in Initial Formation, Build Readers

\section{Introduction}

In order to start to this text, it is necessary to clarify our conceptions on the teaching of reading, training reader teachers and what importance lies in this study for such area of expertise. We begin by justifying the relevance of this work registering that while investigating the repository of theses and dissertations available on CAPES (Coordination for the Improvement of Higher Education Personnel) website about researches which focus on the "formation of reader teachers", it is found 73 records, and in only 4 of those there is an explicit concern to articulate the formation of teacher as proficient reader, with their function of forming new fluent readers. Another issue worth mentioning is the role of school in the formation of readers, and Amorim (2009) clearly records when commenting the researches in Brazil: "[...] the school is failing in its mission of forming readers who like to read and will continue to do so even after they are away from it. That is, in addition to master the techniques of reading skills (when learning actually happens, as international measurements indicate that the performance of Brazilian students in reading comprehension is poor when compared to colleagues from other countries) do so with pleasure (Amorim, 2009: p. 171). 
If our intention is to identify how the teacher training courses work reading into their curricula and, as taught to the teacher the referrals which should give their practice in order to better teach their students to read proficiently, we must consider very often the lack of a theoretical basis, leaving these future teachers to reproduce the practice of their old teachers. On this, Silva (1998: p. 70) states: "If the general framework for teacher training in recent times can be described as weak, their prior preparation to forwarding reading at school can be considered extremely weak or simply null”.

Perhaps this may be explained in the fact that school teaches reading, but does not propose tasks involving social practices of reading and writing for students to practice such skill. We assume that it is not completely believed the idea that this should be done, in a continuous process, so that they give account including complex texts, which are indispensable for the formation of the complete reader. Unfortunately, even with all the theoretical production that denies this logic, yet many consider reading as a skill that, once acquired, can be replicated without any problems to the different genres of texts. This inconsistency was evident when we analyzed the data collected from the survey of the Pro-Book Institute (IPL), held in 2015, based on 5012 interviews applied in 315 Brazilian municipalities, under the Reading Pictures theme in Brazil. This study aimed to identify the Brazilians reading habits, and it was found that the influence of the teacher for the formation of the proficient reader was much lower if compared to other influences or the lack of them, as we see in Figure 1.

Within this context, we consider that the future teachers have the right to real reading practices during their initial formation, so that it is meaningful and consistent for a professionalization resulting from educational choices and coherent with the reading needs of their students. Not any reading, but one that brings as consequence the emancipation and autonomy, which is defended by Silva (1998) when he says: "this way, the critical reading, one that unveils, shows and requires placements, can significantly contribute in the turn of events, in the exit of the oppressive world and, consequently, in the search for a happier and more productive life in society" (1998: p. 73).

We assume that the formation of teachers involves more elements than those contained in the space-time education and work: the school and the formal education. Evidently, this process of formation begins before school and extends beyond it, but this fact does not take away from the initial training the responsibility for expanding the literacy and for creating opportunities to undergraduates to experience real social reading practices involving different textual genres.

In agreement with the theorists who have argued the need to focus on the aspects which are related to the training of teachers in order to seek alternatives for teaching qualification (Tardif, 2002; Freire, 2001; Guimarães, 2004: Gatti, 2010), we aim to, within the limits of this work, analyze the initial process of reader building of teachers graduated in Bachelor in Language Arts. The questions which guided this study were as follows: Has the Bachelor in Language Arts provided an initial training that guides the constitution of the fluent reader? In the case of an affirmative answer, how is it planned to happen?

For consistent answers to these research problems, we organized, in a quantitative and qualitative approach, an inventory and the analysis of teaching plans of undergraduate teachers of the Bachelor in Language Arts of a

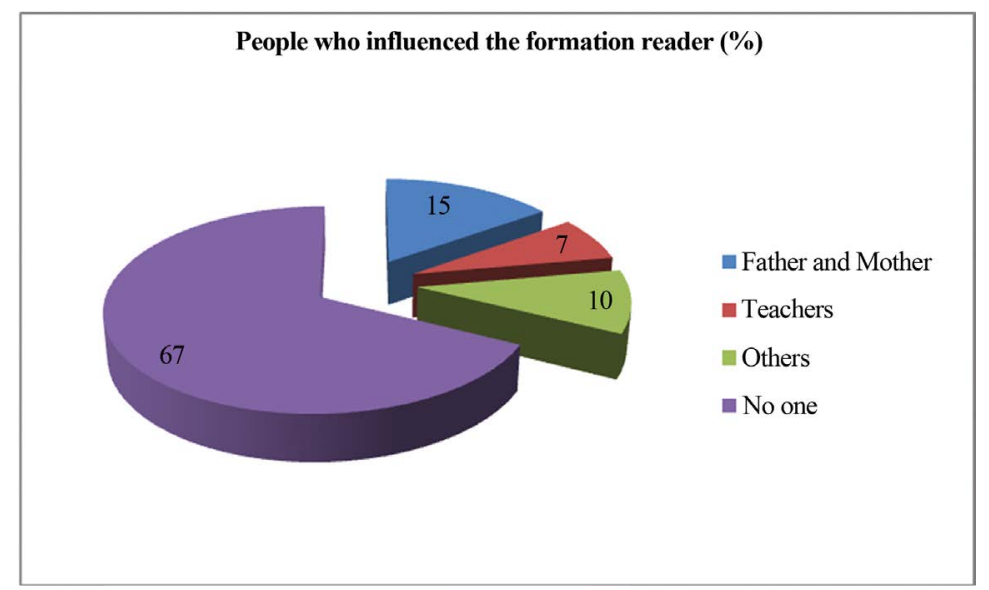

Figure 1. Influence of people in the reader's formation. Source: Pro-book institute (IPÇ)/portraits of reading in Brazil, 2015. 
public university in the state of São Paulo, with an emphasis on records of syllabus, objectives and bibliography. For data analysis obtained it was used the theoretical foundations that sustain the study: conceptions of reading and ways of reading as a cultural practice (Chartier); language as an instrument of mediation (Vygotsky) and as enunciation process (Bakhtin).

\section{The Concepts and Guidelines}

\subsection{Assumption of Reading}

It is assumed here the assumption that reading is to understand and give meaning to a written text. This process comprises an interaction between the active thinking of the reader-mediated by all his previous "readings" and what the text says. We also assume that the act of reading is always conditioned by both the context of production of the text, as well as its circulation sphere and the reading purpose. On this account, we record the statement of Silva \& Balsan (2013): "[...] we must reflect on how to teach reading. This means that it is not just a cognitive issue and the decoding of the written code, but a complex understanding that requires the use of specific strategies that must be taught to children” (Silva \& Balsan, 2013: p. 83).

Contemporary society requires a fluent reader. We live immersed in an iconic, imagistic and graphocentric world, with photographs, billboards, newspaper headlines, traffic signs, checks, invoices, documents, labels, magazines, books, among others. The contemporaneity requires readers full time, but it is clear we do not read in the same way the texts of different genres which are presented, and not everyone has access to the necessary reading experience to use literacy as a coping tool to face the challenges relevant to the social practices of current daily life.

It is the role of school to provide students, through the reading practices there experienced, the necessary tools so that they can organize complex information regarding the contemporary world and to exercise the right to read "to understand the world" and write "to transform it" (Bernardo, 1986: p. 3).

The learner depends on the mediation of the other, while experienced individual, to autonomously consolidate the activities and the reading strategies. Vygotsky (1987) highlights the unique role of such experienced individual in the development of the learner. In this perspective, the proposal of reading activity as a result of interactions starts from the principle that the text allows multiple interpretations and that it is the teacher's role to mediate the information that belongs to a wider social sphere than the one the student takes part. Therefore, the student builds his/her reader proficiency as he/she triggers prior knowledge on the subject, genre, author, makes inferences, raises hypotheses, makes anticipations about what can be treated in the text and the way it will be registered. Thus, he/she is transformed into a reader able to understand not only what is explicit in the text, but also what is implied. For that to happen, the teacher must provide the student with opportunities to experience the universe of reading and find out how much it is broad and diverse. He/She should also propose activities that mobilize different individual reading strategies, apart from situating this practice in their social universe of use, recovering the context of the production of the text that is being read.

We defend the idea that a teacher as a fluent reader could, with far more property, promote a reading work which would contribute to the formation of reader students, who would be able to understand a text thoroughly. A teacher who has not made himself a reader will not be able to promote what proposes Barthes (1992): make the reader no longer a consumer but a producer of texts, as you complete the gaps, plunging into the subjectivity of the texts in search of less explicit meanings. The word reading cannot ignore the knowledge and the reading of the world that each reader has (Freire, 1994: p. 11), which were acquired on their experiences in their own reality and social context.

\subsection{Maintaining the Integrity of the Specifications}

National curriculum guidelines for the Bachelor of Language Arts, on clarifying the role of the teacher, in face of what was being proposed, records that the implementation of the new curriculum, "requires the deployment of the teacher role in the figure of the advisor, who should not respond only for teaching course contents, but also for the quality of the student education” (Brazil, 2001).

It is contained in such statute, the following guidance on the necessary skills and abilities that should be guaranteed to the future teacher of Language Arts: "the development of specific skills and abilities [...] that must be "founded on the perception of language and literature as a social practice and as the most elaborate form of cultural manifestations. Must articulate the theoretical and critical reflection with practice areas-essential for 
Language Arts professionals” [...] (Brazil, 2001).

The Opinion CNE/CES 492/2001 claims to be "necessary to broaden the concept of curriculum, which should be conceived as a cultural construction that provides the acquisition of knowledge in an articulate manner." In terms of the national guidelines, the curriculum of a formation course "should be made by both the set of knowledge, skills and abilities, as the goals that seeks to achieve” (Brazil, 2001: p. 50).

According to the National Curriculum Parameters of Portuguese Language (Brazil, 1998), it is up to the teacher set out the planning, the implementation and the organization of educational activities, "in order to trigger, support and guide the efforts of action and reflection of the student, seeking to ensure effective learning "(p. 22). He must further assume the "role of informant and privileged interlocutor who thematizes priority issues depending on the needs of the students and their learning opportunities" (p. 22).

As the official documents indicate, the teacher's role as mediator in the formation of proficient readers necessarily requires their own constitution as a reader. If prior knowledge, given by the reading of texts from different genres, is a major factor in acquiring reading abilities, and if, according to the conceptions of reading and ways of reading as a cultural practice (Chartier), the language as a means of mediation (Vygotsky), the formation for reading must take place in real social practices, then it would also be crucial that the curricula of undergraduate programs prioritize such a procedure so as not to occur anymore what is recorded in the official text; the "failure of the objectives related to the reader's formation” (Brazil, 1998: p. 32).

\section{What the Lesson Plans Tell Us}

By agreeing with Libâneo (2013) that the education plan is a guide with the role of supporting the teaching practice and for that their role should be consistent when it comes to objectives, contents and methods is why we try to analyze the teaching plans of Letters course teachers. We did this with the intention of identifying possible approaches and/or distances between training purposes of their students, future teachers, as full readers and the objectives, contents and methods that are being prioritized in teaching plans.

The official curriculum of the degree course in Letters we reviewed, offers 54 subjects in the area of General Basic Training and Methodological Training and Practice over the 4 years of regular academic student route. To carry out analysis of teachers' lesson plans we left out of data collection only 16 plans of curricular components that are meant for foreign language teaching, the others, in a total of 38 teaching plans, we analyzed mainly observing the information contained in the menus, the objectives and the bibliography used.

The first category of analysis we used was to check if the expression "Reader Formation" was present at some of the items in the teaching plan. The prioritization of this analytical category was intended to meet the proposed research objectives which were to identify the guidelines that orientates the initial training of the reading teacher and analyze the effects of the reading experiences in the initial training (bachelor). After reading all the 38 selected plans, it became clear that none of them includes the expression "reader formation".

The second category of analysis was to try to identify in the teaching plans some reference to working with reading that were stated in the objectives listed in the document, that is, what subjects had the explicit goal of working with reading practices. To perform this analysis, we construct in Table 1.

From this analysis we concluded that: 1) 14 plans record on their goals a concern about reading; 2) in these plans, this concern appears recorded among the subjects' objectives, only once; 3) 8 teachers are responsible for providing these subjects; 4) of the 14 objectives for reading that were found in the teaching plans, 7 of them have the same intention: "Sensitizing the student to the habit of reading, writing and defending views", others still appear with the same proposal between them, which is " Developing in the student a taste for reading literary texts and the issues involved in them”; 5) goals that have reading, understanding and interpretation as separate and sequential activities appear twice: "reading, understanding, analyzing and interpreting works/literary texts “; 6) Only 1 goal appears contemplating the reading of different genres texts: "Reading critically different types of text"; 7) Finally, we identified that one of the objectives introduces the concept that there is a "satisfactory" way to read the literary text and it must occur in "opposition" to non-literary texts.

\section{Final Considerations}

The collected data were analyzed according to the assumptions on reading, the ways of reading as a cultural practice, and language as an instrument of mediation. These data indicate that the future teacher, graduated in the Bachelor in Language Arts researched, is not having in their degree appropriate and meaningful opportunities to be a 
Table 1. Reading goals by discipline.

\begin{tabular}{|c|c|c|}
\hline Subject & Objective & Prof. \\
\hline Portuguese Language IV & $\begin{array}{l}\text { Using the reading/writing as an active process of recognition, } \\
\text { interpretation and transformation of the world. }\end{array}$ & A \\
\hline $\begin{array}{l}\text { Reading and production of texts: Introduction } \\
\text { to language and literature studies I }\end{array}$ & $\begin{array}{c}\text { Sensitizing the student to the habit of reading, writing and defending } \\
\text { views }\end{array}$ & B \\
\hline $\begin{array}{l}\text { Reading and production of texts: Introduction } \\
\text { to language and literature studies II }\end{array}$ & Reading critically different types of text & B \\
\hline Mother Language Laboratory Practice I & $\begin{array}{c}\text { Sensitizing the student to the habit of reading, writing and defending } \\
\text { views }\end{array}$ & $\mathrm{C} / \mathrm{E} / \mathrm{F}$ \\
\hline Mother Language Laboratory Practice II & $\begin{array}{c}\text { Sensitizing the student to the habit of reading, writing and defending } \\
\text { views }\end{array}$ & $\mathrm{C}$ \\
\hline Mother Language Laboratory Practice III & $\begin{array}{l}\text { Awakening in the student the sensitivity to the habit of reading, writing } \\
\text { and defending views }\end{array}$ & B \\
\hline Mother Language Laboratory Practice IV & $\begin{array}{c}\text { Causing the student to be aware of the habit of reading, writing and } \\
\text { defending views }\end{array}$ & B \\
\hline Mother Language Laboratory Practice V & $\begin{array}{c}\text { Sensitizing the student to the habit of reading, writing and defending } \\
\text { views }\end{array}$ & $\mathrm{C}$ \\
\hline Mother Language Laboratory Practice VI & $\begin{array}{c}\text { Sensitizing the student to the habit of reading, writing and defending } \\
\text { views }\end{array}$ & A \\
\hline Brazilian literature II & $\begin{array}{l}\text { Reading, understanding, analyzing and interpreting representative works } \\
\text { of different trends in the Brazilian literature consolidation period. }\end{array}$ & G \\
\hline Brazilian literature III & $\begin{array}{l}\text { Developing in the student a taste for reading literary texts and the } \\
\text { issues involved in them. }\end{array}$ & $\mathrm{H}$ \\
\hline Brazilian literature IV & $\begin{array}{l}\text { Developing in the student a taste for reading literary texts and the } \\
\text { issues involved in them. }\end{array}$ & $\mathrm{H}$ \\
\hline Brazilian literature V & $\begin{array}{l}\text { Reading, analyzing and interpreting significant literary texts of this } \\
\text { period (1930-1970) }\end{array}$ & $\mathrm{H}$ \\
\hline $\begin{array}{l}\text { Studies of language: language and literature } \\
\text { topics II }\end{array}$ & $\begin{array}{l}\text { Reading in a satisfactory way the literary text, understanding it in its } \\
\text { various aspects and in opposition to the non-literary text. }\end{array}$ & $\mathrm{E}$ \\
\hline
\end{tabular}

Source: Data collected by the authors.

reader teacher. This is because very few plans have goals focused on the teaching of reading and it cannot be detected among the educational plans analyzed, any which will prioritize the didacticism of the teaching of reading. This absence, definitely, has implications for the teaching practice of the future teachers, because only a consistent initial training, based on actual social reading practices will enable that teacher the competence to organize their daily practice, articulated with the development of comprehension skills of meanings and meanings of texts from different genres to their students.

\section{References}

Amorim, G. (2009). Os muitos retratos da leitura no Brasil. Formar leitores para ler o mundo. Lisboa: Casa da LeituraFundação Calouste Gulbenkian.

Barthes, R. (1992). S/Z. Rio de Janeiro: Nova Fronteira.

Bernardo, G. (1986). Redação Inquieta (2nd ed.). Porto Alegre: Globo.

Brazil (2001). Mec-Parecer Conselho Nacional de Educação/Câmera de Ensino Superior 492/2001-Diretrizes curriculares para os cursos de letras. Diário Oficial da União de 9/7/2001, Seção 1e, 50.

Brazil (1998). Parâmetros Curriculares Nacionais de Língua Portuguesa para o Ensino Fundamental. Imprensa Oficial: Brasília. http://portal.mec.gov.br/seb/arquivos/pdf/livro02.pdf

Freire, P. (1994). A importância do ato de ler: Em três artigos que se completam (29th ed.). São Paulo: Cortez.

Freire, P. (2001). Pedagogia da Autonomia: Saberes necessários à prática educativa (19th ed.). São Paulo: Paz e Terra.

Gatti, B. A. (2010). Formação de professores no Brasil: Características e problemas. Educação e Sociedade, 31, $1355-1379$.

Guimarães, V. S. (2004). Formação de professores: Saberes, identidade e profissão. Campinas: Papirus.

Libâneo, J. C. O (2013). A elaboração de planos de ensino (ou de unidades didáticas) conforme a teoria do ensino desen- 
volvimental. http://professor.pucgoias.edu.br/SiteDocente/home/disciplina.asp?key=5146\&id=3552

Silva, E. T. (1998). Criticidade e Leitura: Ensaios. São Paulo: Mercado de Letras.

Silva, J. R., \& Balsan, S. F. S. (2013). Estratégia de leitura, de Isabel Solé: um caminho para a formação de leitores. In R. J. Souza, \& B. L. T. Feba (Eds.). Ações para a formação do leitor literário: Da teoria à prática. Assis (SP): Storbem Gráfica e Editora.

Tardif, M. (2002). Saberes Docentes e Formação Profissional. Petrópolis (RJ): Vozes.

Vygotsky, L. S. (1987) A formação social da mente. São Paulo: Martins Fontes.

\section{Submit or recommend next manuscript to SCIRP and we will provide best service for you:}

Accepting pre-submission inquiries through Email, Facebook, Linkedin, Twitter, etc A wide selection of journals (inclusive of 9 subjects, more than 200 journals)

Providing a 24-hour high-quality service

User-friendly online submission system

Fair and swift peer-review system

Efficient typesetting and proofreading procedure

Display of the result of downloads and visits, as well as the number of cited articles

Maximum dissemination of your research work

Submit your manuscript at: http://papersubmission.scirp.org/ 